\title{
The menace of public toilets in institutional housing: case studies of selected universities in South-West Nigeria
}

\author{
G. Fadairo \& Y. M. D. Adedeji \\ Department of Architecture, Federal University of Technology, \\ Akure, Nigeria
}

\begin{abstract}
The role of public toilet facilities in Nigerian universities cannot be underplayed because it is important in the sanitation enhancement of campus environment. Public toilets matter to everybody, regardless of their age, class, ethnic origin, gender, mental ability or physical ability. The harmony of a building would not be complete without it. A close observation of universities environment without adequate public toilet facilities at strategic locations is an impediment to its assumption of a full-fledged academic environment. This paper examines the provision, sanitation, and management of public toilets using Federal University of Technology, Akure; Obafemi Awolowo University, Ile-Ife and University of Lagos, Akoka as case studies. Findings revealed the unhealthy conditions of toilet facilities in institutional housing and recommends waterless toilet facilities for institutional buildings in Nigeria.

Keywords: environment, facilities, housing, institutional, management, Nigeria, planning, provision, public toilet, sanitation.
\end{abstract}

\section{Introduction}

The Nigerian universities constitute an important resource in the national educational development. It is the source of the nation's development. It is endowed with human and technological know-how resources which are exploited to produce people who are knowledgeable to meet public and industrial consumption needs of the country as well as the international requirement [1]. Yet, the Nigerian tertiary institutions have suffered serious neglect and left to cater for its own environmental sanitation needs in terms of public toilet 
provision, planning and management. This is in spite of the fact that tertiary institutions in Nigeria accommodate the largest majority of enlightened people in the country. It has been estimated that Nigeria has eighty six (86) universities, out of which Federal universities are twenty five (25), State universities thirty (30) and Private universities thirty one (31) aside the Polytechnics and colleges of education as indicated in Table 1 below.

Table 1: Classification of universities' ownership in Nigeria.

\begin{tabular}{|l|l|l|l|}
\hline S/No & \multicolumn{1}{|c|}{ Ownership } & Number & Percentage of Ownership \\
\hline 1 & Federal Universities & 25 & $29.1 \%$ \\
\hline 2 & State Universities & 30 & $34.9 \%$ \\
\hline 3 & Private Universities & 31 & $36.0 \%$ \\
\hline & Total & 86 & $100 \%$ \\
\hline
\end{tabular}

Source: Joint Admission and Matriculation Board (JAMB) 2009/2010.

Health and safety are the most fundamental requirements of habitable buildings. Unlike the observable characteristics of a building (e.g. exterior design and ancillary facilities), its health and safety performance is usually unknown before it is inhabited. Besides, health and safety hazards are not confined to building owners but can also adversely affect users, visitors and passer-by [2]. A survey carried in 1997 indicated that about $15 \%$ of the population of Nigeria did not have access to safe excreta disposal facilities and that about $75 \%$ of the populace uses pit latrines. The situation throughout the country is thought to be worse than this, with many facilities not operational or not well maintained. About $60 \%$ of the people were shown to discharge their waste water directly to the environment with no consideration of aesthetic or health consequences. Most residents have no organised way of dealing with their solid waste [3]. Today, the Nigerian tertiary institutions are characterised by a number of drawbacks to sustainable neat environment. These include inadequate toilet facilities in public buildings, lack of constant water supply to the available toilets, dwindling power supply in the available toilet environments among others. These have translated into a number of problems thereby exposing university communities into series of health risks [4]. The National University Commission (NUC) standard recommends one toilet to ten students (1:10) [1].

The Nigerian Government has long considered the provision of water supply and sanitation services to be the domain of the federal, state and local governments. However, the public sector has not been successful in meeting more than a small portion of the demand for water and sanitation of residential and commercial users. A demographic and health survey (DHS) carried out by National Planning Commission and ORC Macro in 2003 noted that services are in critically short supply. For example, out of the 85 million people living in urban and semi-urban areas, less than half have reasonable access to reliable water supply. Water supply services, where they exist, are unreliable and of low quality and are not sustainable because of difficulties in management, operation and pricing and failure to recover costs. Many water supply systems show 
extensive deterioration and poor utilization of existing capacities, due to undermaintenance and lack of funds for operation [5].

Linkages between water supply and sanitation (WSS) and a cluster of key sectors, including health, education, agriculture, and environment are intuitively obvious, and documented with varying precision in different developing countries. Some of the data and project experience in Nigeria in these sectors suggest clear linkages between poor WSS standards and decline in indicators in health, education and productivity. Specifically, these include low enrolment in schools, particularly of girls who must spend time collecting water, higher crime against women due to lack of toilet privacy, as well as the more obvious impacts of disease, higher infant mortality, high absenteeism in schools and at work, and lower productivity [6].

Nigeria is not on track to meet the MDG target for sanitation of 70 percent access by 2015. United Nations sources estimate that in the last fifteen years rural sanitation access rates have risen just 3\%, from $33 \%$ in 1990 to $36 \%$ in 2004, while urban sanitation access has gone from 51\% to 53\% [7]. The present impasse in the construction of public toilet on campuses and by implication, in answering the call of nature among the university community, makes it imperative that public toilets need to be well planned and maintained to the best opportunity available toward a hygienic environment in universities.

\section{The changing demands university community}

For just fifty-one years of independence, the Nigeria nation has undergone fundamental changes in all spheres of human activities having gone through a complete circle of development from the stable position of the 1960s down to the new millennium. These changes have had tremendous influence on the quality of environment in the tertiary institutions in Nigeria [8].

The traditional needs of our community are gradually giving way to their wants and as such, the emphasis in public toilet provision in the university campuses out to shift from providing the needs of the society to ensuring the availability of our wants. Toilet provision must thus be increased to accommodate the changing tertiary society. As at now, visible unenlightened conditions are building up in the university environment as to how people urinate in non-designated places on campuses especially at bus stops, parking lots, amongst others [9]. Sanitary facilities in most urban dwellings and public services (especially water and electricity supply) are grossly inadequate [10].

\subsection{Institutional buildings and environmental degradation}

An institution is a large organisation that is influential in the community i.e. college, hospital, banks etc. [11]. These influences result from the output of products and services rendered to the surrounding host community under the leadership of one or a group of elect having managerial capacity for effective administration. An institutional housing refers to the housing stock, which is under the control of the institutional council, usually provided for by 
organisation to provide accommodation and a comfortable environment for productivity. However, such housing can be owned or leased by the institution as well as through public-private partnership agreement with individuals, companies, cooperative and non-governmental organisations [12]. Institutional housing includes office buildings, workshops, laboratories, auditoria, students and staff housing among others.

Housing in all its ramifications is more than mere shelter since it embraces all the social services and utilities that go to make a community or neighbourhood a liveable environment. Housing is a holistic phenomenon which inculcates the provision of shelter with other social, economic and physical considerations needed for the well being of the intended occupants and citizenries [13]. Thus, housing includes the physical, infrastructure (utilities), social services and other qualities of the environment that contribute to making a community or neighbourhood a liveable environment [14]. A report on urban household survey carried out on major towns in Nigeria by the Federal Office of Statistics in 1979 reveals that $47.9 \%$ of urban households are without electricity. Similarly, $58.89 \%$ were without treated pipe-borne water. Inadequate provision of toilet facilities, bathrooms, kitchen, plumbing and refuse disposal in houses are other sources of environmental degradation in Nigeria [15]. Hence, it is clearly evident that the quality of toilet facilities in many residential neighbourhood in Nigeria are deplorable conditions and does affects the quality of livelihood of the occupant of these spaces.

\section{Research methodology}

The data obtained for the paper were based on case studies of selected universities in South-Western zone of Nigeria. Three institutions were purposively selected based on the economic conditions of the nation at the time of their establishment and ownership. The selected institutions are:

1. University of Lagos, Lagos (UNILAG) established in 1962;

2. Obafemi Awolowo University, Ile-Ife (OAU) established in 1962 and

3. Federal University of Technology, Akure (FUTA) established in 1981.

University of Lagos and Obafemi Awolowo University, Ile-Ife were established shortly after the nation's independence when the economy was booming and stable. Most facilities were adequate and functional at inception. The two institutions together with Federal University of Technology, Akure were established and owned by the Federal government of Nigeria. In the case of FUTA it was established in 1980's when the economy of the nation has started to experience crises. Facilities in many institutions established during this period are grossly inadequate.

Besides, a well-structured questionnaire, which was designed to investigate 25 variables on institutional housing, was used to elicit opinions of users on the use of these facilities. The variables, structured in question form, written in English language, and responses required in pre-coded alternatives given were targeted to elicit responses from students that uses the toilet facilities. Research 
assistants, who had earlier been trained by the author, administered the questionnaire to the respondents (Table 2).

The housing variables investigated include method of refuse disposal, and quality of toilet and bathroom services measured by condition of appliances, water supply measured by its sources, condition of sanitary services measured by toilet types, drainage conditions. It also considers the condition of the totality of environment around hostels and facilities provided.

Table 2: Questionnaire distribution in the selected institutions.

\begin{tabular}{|l|l|l|l|}
\hline $\mathrm{S} / \mathrm{n}$ & Institution & No of Respondents & Percentage of Respondents \\
\hline 1 & UNILAG & 748 & 636 \\
\hline 2 & OAU & 1760 & 1390 \\
\hline 3 & FUTA & 832 & 479 \\
\hline & Total & 3340 & 2505 \\
\hline
\end{tabular}

Source: Field Survey, 2010.

\section{Results and discussion}

Findings are discussed under two broad sections, revealing the unhealthy conditions of toilet facilities in institutional housing in the selected Universities. These include case studies of some selected students' accommodations with photo prints to show the existing conditions of these facilities and users' responses on the efficiency of these facilities with their causative factors as discussed in 4.1-4.3.

\subsection{Case study one: Jaja Hall, University of Lagos, Lagos}

Located in the main campus and sited adjacent to the Chemical Engineering Department and Jaja Shopping Complex, Jaja Hall of residence is one of the most prominent male hostels in the University of Lagos. The hostel is a four storey building with 180 rooms, nine of which accommodate eight (8) students per room, another nine (9) accommodate six (6) students per room, thirteen (13) are two students per room with the remaining being four (4) students per room. A total number of seven hundred and forty-eight (748) residents live in this hall of residence. At the wings of each floor are toilet and bathroom facilities. The toilets are fitted with floor and wall tiles but with inadequate supply of water for these facilities.

\subsection{Case study two: Fajuyi Hall, Obafemi Awolowo University, Ile-Ife}

Fajuyi hall was randomly selected out of the hostels for students of the institution. It is a male hostel located close to the academic core area. The hostel has eleven blocks of buildings spanning four (4) floors with annexes. Each block of forty rooms was designed to accommodate four hundred and forty (440) students. The buildings were built in such that the facilities comprise of four (4) 
water closets and four (4) showers arranged directly opposite each other. The area is lit through the use of screen wall by the sides. External walls are $225 \mathrm{~mm}$ thick sandcrete blocks while internal walls are $150 \mathrm{~mm}$ thick.

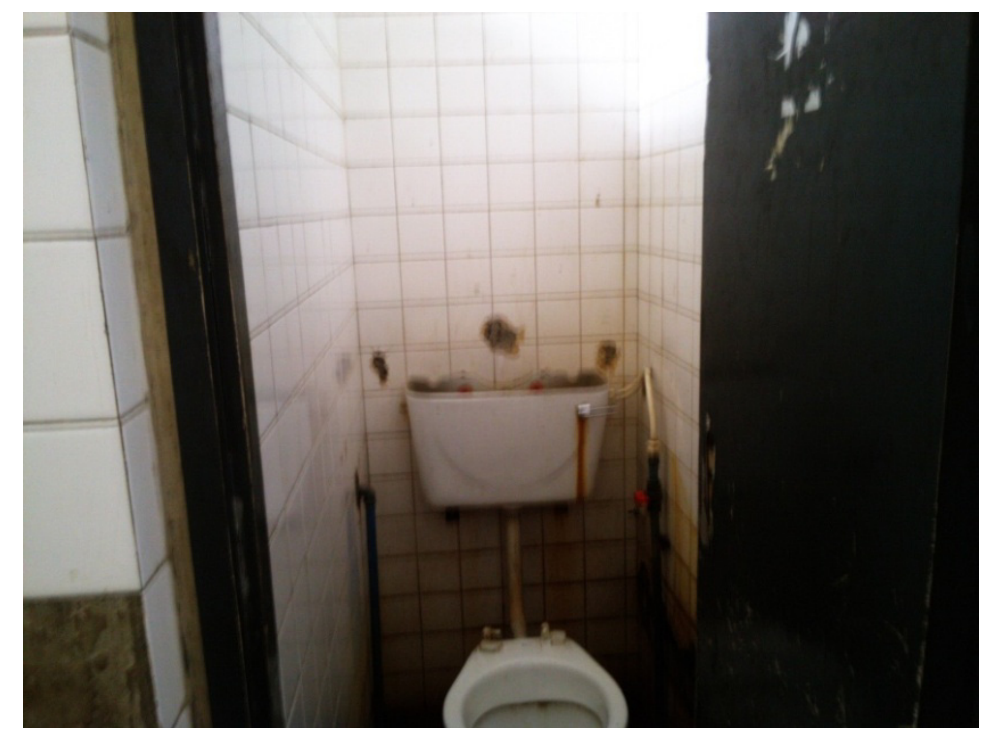

Figure 1: $\quad$ A case of an unmaintained toilet in Jaja Hall of Residence.

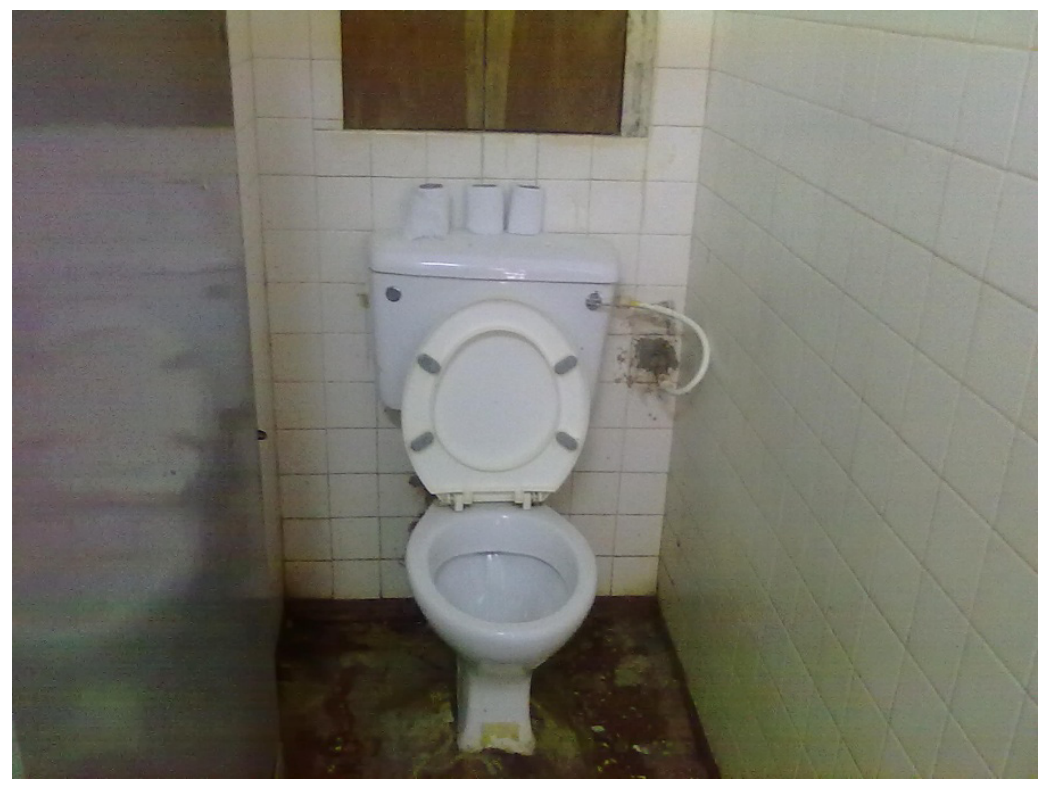

Figure 2: A case of a poorly maintained toilet in Fajuyi Hall, OAU, Ile-Ife. 
The hall has a common access lobby making accessibility easy for users. Common features in the buildings are:

1. Toilets and bathrooms are spacious enough to accommodate users comfortably;

2. Standard sanitary appliances;

3. Poor lighting systems toward water closets;

4. Moribund flushing cisterns;

5. Pipe leakages, leaving water on floors thereby causing slippery and dampness to floors;

6. Inadequacy of water supply and

7. Poorly maintained facilities.

\subsection{Case study three: Akindeko Hall, federal university of technology,} Akure

The Federal University of Technology, Akure (FUTA) presently has three (3) hostels for students' accommodation, two of which are for male students. Akindeko hall, according to the students, which form the heart-beat of FUTA and a hall of residence for male students, was selected out of the three residences. The toilet and bath facilities in this hall are abusively used due to short shortage of water supply and poor maintenance. Some of the toilet cisterns are broken and non-functional. Wall and floor finishes were observed to have been out of place while some doors and windows are broken. Toilets and bath environment was observed to be generally dirty and unhealthy for human use.

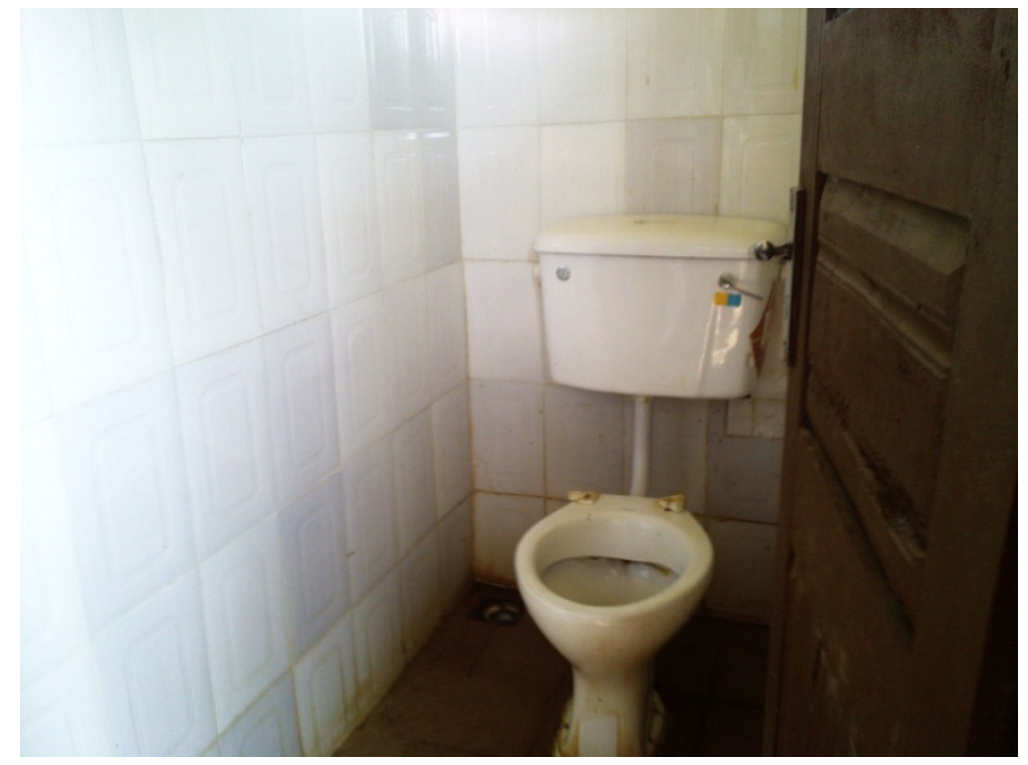

Figure 3: Non-functional water closet in Akindeko Hall, FUTA with defaced floor and a broken door. 


\subsection{Analysis of data on the assessment of toilet facilities in the selected institutions}

Data obtained through structured questionnaire were collated and analysed with a frequency table shown in Table 3 below. Meanwhile, only 2505 of the 3340 questionnaires administered were retrieved. These were used for the data analysis, representing $75 \%$ of the expected responses. Assessment of conditions of toilet facilities in selected institutions reveal that facilities are below average in these institutions as reflected in Table 3 below:

Table 3: Respondent's assessment of conditions of toilet facilities in the selected institutions.

\begin{tabular}{|c|c|c|c|}
\hline S/no & Ratings & No of Respondents & Percentage of Respondents \\
\hline 1 & Poor & 918 & 36.67 \\
\hline 2 & Fair & 459 & 18.33 \\
\hline 3 & Average & 418 & 16.67 \\
\hline 4 & Good & 668 & 26.67 \\
\hline 5 & Excellent & 42 & 1.67 \\
\hline & Total & 2505 & 100 \\
\hline
\end{tabular}

Source: Field Survey, 2010.

$55 \%$ of respondents rated the conditions of toilets to be below average, most of which are located in unkempt environment without adequate covers and rings. Only $28.3 \%$ of respondents agreed that toilet facilities in the hostels are above average. Majority of these respondents are domicile in recently built accommodations or renovated in recent times. Main problems prevalent in these toilets are lack of adequate water supply; poor usage and inadequate maintenance of public facilities in these institutions. These observations agreed with earlier observations noted by FUTA Giant Strides [16].

\section{Technology initiative in toilet facilities}

The MDG goal is for "basic sanitation", which usually means a simple low-cost pit latrine that is safe to use. In Nigeria, the national policy specifies an improved traditional pit latrine as the minimum standard. In many cases such latrines can be built mainly from local materials by households and communities with the support of community WASCOMs (Water and Sanitation Committees), sanicentres and entrepreneurs. Such facilities should be designed and constructed as an essential element of the students' accommodation [10].

Institutional and public sanitation facilities constructed will be toilets that meet national standards as specified by the relevant ministries and policy instruments (Federal Ministries of Agriculture and Water Resources, Federal Ministry of Environment, Housing and Urban Development, Federal Ministry of Health and Federal Ministry of Education). The technologies employed in the provision of toilet facilities vary with type of toilet facilities. Even for the 
common types of toilet facilities known in third world countries like, seating type water closet, squatting type water closet, enviro-loo type of water closet, among others; technologies vary between high cost one and low-cost ones.

Enviro-loo type of water closet is a waterless sanitation system which has been tested and proven to be effective in human solid waste processing as well as being environmentally friendly [17]. This type of toilet facilities was installed in FUTA as public toilet facilities. It was conceived as a vehicle to provide and deliver desperately needed sanitation and clean water to the generality of the people on campus communities (Figure 4).

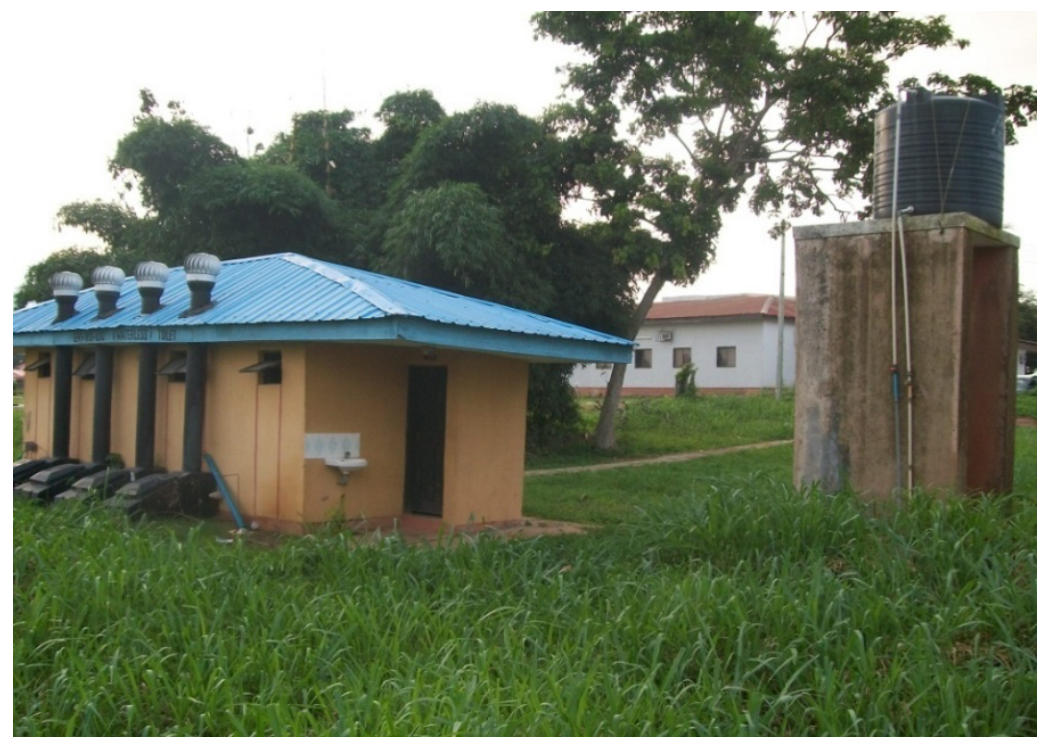

Figure 4: $\quad$ Showing typical Enviro-Loo public toilet facilities in FUTA.

Many public toilets in Nigeria are not functional owing to lack of adequate maintenance and regular supply of electrical energy to power water supply into these toilets. Electricity is indispensable for certain building related activities, such as lighting, refrigeration, operation of household appliances, structural/body cooling and structural/body heating cannot easily be replaced by other forms of energy. The populace's access to electricity is an indication of a country's electricity poverty status than do statistics on their average consumption. The per capita consumption data can give a distorted impression where a very small minority consumes enormous amount of electricity, while the majority consumes practically none [18]. This phenomenal problem has warranted an urgent need to evolve an energy strategy that is affordable and sustainable. Besides, there is the need for the employment of sanitation agencies that will be responsible for the maintenance of these toilets on regular basis to increase good quality public toilets and enhance hygienic environment. These could also be contracted to 
proven contractors that will ensure enforcement of standards for healthy students' environment. Some have opted for a scheme where the local authority works in partnership with local businesses. Various strategies for the provision of clean, safe, accessible toilets should be deployed.

\subsection{Recommendations}

The health section plays a crucial role in protecting the health of university communities from a variety of risks. The following recommendations are proposed:

1. Priorities should include preventive and dissemination of information about hygiene, health advocacy campaigns in universities.

2. Develop collaboration and partnership mechanisms amongst key stakeholders.

3. Prioritise sanitation and hygiene within development plans of institutions.

4. Increase funding levels for public toilets, sanitation and hygiene programmes from existing budgets.

5. Finalise and widely disseminate harmonised policy and strategies.

6. Enforce national standards for sanitation and hygiene facilities in universities.

7. Continue to support the creation of environmental health clubs in tertiary institutions

8. Incorporate health and social criteria as well as environmental management in the student information handbook as one of the admission requirement.

9. Easy accessibility of toilet facilities should be ensured in all buildings within the universities.

\subsection{Conclusion}

This paper has sought to review the provision, performance and management of public toilet facilities in Nigeria universities with particular reference to the selected Universities in South-Western zone of Nigeria - The Federal university of Technology, Akure (FUTA); University of Lagos, Lagos (UNILAG) and Obafemi Awolowo University, Ile-Ife (OAU). While prevalent issues associated it public toilet in institutional buildings were highlighted, appropriate technology for provision of waterless toilet that would satisfy basic sanitation and hygiene in university environments was suggested. Approaches to public toilet facilities issues, however, varies greatly by local context, even within Nigeria. The authors hope this paper will serve as useful starting point for public toilet facilities in provision, performance and management in Nigeria universities.

\section{References}

[1] Joint Admission and Matriculation Board JAMB, Guidelines for Admissions to First Degree Courses in Universities and other Degree Awarding Institutions in Nigeria. JAMB Publisher, pp.20-25, 2009/2010. 
[2] Chau, K. W., Ho, D. C. W., Leung, H. F., Cheung, A. K. C., Yau, Y., Lau, S. S. Y. and Wong, W. S., A sustainable framework of building quality assessment for enhancing urban environment. 2005 World Sustainable Building Conference, Tokyo, Japan, 27-29 September, 2005.

[3] Federal Republic of Nigeria, Water Supply \& Sanitation Interim Strategy Note November, pp.2-6, 2000.

[4] National University Commission (NUC/SSF), Self-Study Form. Accreditation of Degree Programme in Nigerian Universities, pp.18, 2006.

[5] National Planning Commission and ORC Macro. 2003.

[6] WHO/UNICEF Joint Monitoring Programme for Water Supply and Sanitation (JMP), Meeting the MDG drinking water and sanitation target: the urban and rural challenge of the decade (2004 data set), 2006.

[7] Federal Ministry of Agriculture and Water Resources, International Year of Sanitation, Action Plan for Nigeria, pp.7-9. 2008.

[8] March, A.D., Gordon, P., Heslop, and Pantazis, C., Housing deprivation and health: a longitudinal analysis. Housing Studies 15(3), pp.411-428, 2000 .

[9] Abumere, S.I., Okafor, S.I. and Oluwasola, Rural Infrastructure and the Development Process in Rural Nigeria. Development Policy Centre, Ibadan. 2002.

[10] Adedeji, Y. M. D., Taiwo, A. A. Olotuah, A. O. and Fadairo, G., Architectural education and sustainable human habitat in Nigeria. Sustainability Today. Ashurst, UK: Wessex Institute of Technology (In Press). 2011.

[11] Encarta, Microsoft Student with Encarta Premium 2007. www.microsoft.com/info/nareturns.htm

[12] Fadairo, G., Impact of Flooding on Urban Housing: A Focus on Ala River in Akure, Nigeria. An unpublished Ph.D Thesis, Department of Architecture, Federal University of Technology, Akure, 2008.

[13] Adedeji, Y.M.D., Materials preference options for sustainable low-income housing in selected cities in Nigeria. An unpublished Ph.D Thesis, Department of Architecture, Federal University of Technology, Akure, 2007.

[14] Federal Republic of Nigeria, National Housing Policy Draft, pp.104-106. January, 2004.

[15] Federal Office of Statistics (FOS), Social Statistics in Nigeria, Abuja. 1997.

[16] Federal University of Technology, Akure (FUTA), Giant Strides. Annual Report November 2008 - October, 2010, Vol. II: pp. 10 \& 57. 2010.

[17] The Maggic Concept, Human Enhancement and Job Creation Project, Abuja: Frencz Limited, 2006.

[18] International Energy Agency, Energy Technology Analysis, $\mathrm{CO}_{2}$ Capture and Storage: A key carbon abatement option, 2004. 